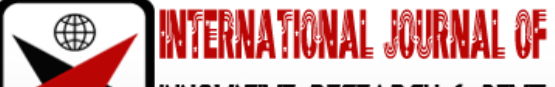

ISSN 2278 - 0211 (Online)

\section{Developing and Validating an Instrument to Measure Students' Attitude towards Electrochemistry}

Philip Dorsah
Senior Chemistry Tutor, Master of Philosophy in Chemistry Education,
Damongo Senior High School, Ghana

\section{Abstract:}

The purpose of the study was to develop and validate an instrument to measure students' attitude towards electrochemistry. The Attitude towards Electrochemistry Scale (ATECS) was developed to measure students' attitude towards electrochemistry. The ATECS was piloted and modified from an initial 20 items to 14 items. The construct validity of the 14 items was determined using factor analysis. The Cronbach's alpha $(\alpha)$ value of the modified ATECS was .906. This provided a strong evidence of reliability. Principal components factor analysis was performed on the 14 items in ATECS with varimax rotation. The Bartlett's Test of Sphericity was significant $\chi^{2}=(261.232), p<0.05$, indicating that correlations between items were sufficiently large for factor analysis. Also, the KMO value of sampling adequacy was .606. Four factors were extracted based on Kaiser's criterion. The statistical data revealed that the ATECS possesses good construct validity and can be used to determine students' attitude towards electrochemistry.

Keywords: Electrochemistry, attitude, factor analysis, reliability

\section{Introduction}

Chemistry curricula commonly incorporate many abstract concepts, which are central to further learning in both chemistry and other sciences (Taber, 2002). Chemistry topics are generally related to or based on the structure of matter, and proved to be a difficult subject for many students (Sirhan, 2007). According to Yochum \& Luoma cited in Sia, Treagust \& Chandrasegaran (2012) students find electrochemistry difficult to master because they cannot observe or imagine what happens in the microscopic level in an electrochemical reaction.

According to Taber as cited in Akram et al. (2014), electrochemistry causes confusion in students and they did not freely assimilate their knowledge across physics and chemistry. Sanger and Greenbowe (1997) cited in Akram et al. (2014) found that students had learning difficulties about galvanic, electrolytic and concentration cells. Research has confirmed that attitudes are linked with academic achievement. Salta and Tzougraki (2004) found that the correlation between high school students' achievement in chemistry and their attitudes toward chemistry ranged from 0.24 to 0.41 . Bennett, Rollnick, Green and White (2001) also found that undergraduate students who had a less positive attitude to chemistry almost invariably obtained lower examination marks. Attitude, motivation, and interest are the most important student characteristics associated with successful studies (Dalgety et al., 2003; Berg, 2005b). Attitude towards chemistry is essential; it denotes interests or feelings towards studying chemistry. Attitude and academic achievement are important outcomes of science education in secondary schools. Students' attitude and interests could play substantial role in students' decision to study science (Abulude, 2009). Another reason why it is important to develop students' positive attitudes toward chemistry lessons is that attitudes predict behaviors (Glasman \& Albarracín, 2006; Kelly, 1988). For example, Kelly cited in Cheung, 2011 reported that British students' liking for a particular science subject was a good predictor of their actual choice of physics, chemistry, or biology in schools.

Research has shown clearly that a negative attitude towards chemistry is the dominant factor affecting student willingness to study further chemistry. Based on social psychological models, it has been shown that attitudes towards topics and themes in chemistry are developed by means of interactive teaching materials. The development of students' positive attitude is necessary because attitude is linked with academic achievement (Cheung, 2009). Weinburgh, (1995) in a meta-analysis of research have summarized that the correlation between students' positive attitude towards science and academic achievement is 0.55 for girls and 0.5 for boys, indicating that an attitude can account for $25-30 \%$ of the variance for academic achievement. Bennett, Rollnick, Green and White (2001) also found that undergraduate students who had developed a lower constructive attitude towards chemistry almost always got low grade in examinations. Olatoye cited in Abulude, 2009 found that students' attitude towards chemistry have significant direct effect on students' achievement in the subject.

Tapia and Marsh cited in Cheung (2009) emphasized that attitude scales must withstand factor analysis, tap important dimensions of attitudes, and require a minimum amount of time for administration. According to Cheung 
attitudinal data, which can be accomplished with confirmatory factor analysis. A systematic examination of the construct validity of attitudinal data is most critical because construct validity subsumes content relevance, content representativeness, and criterion-relatedness, and is the evidential basis of interpretation of data as well as the use of data (Messick, 1989 cited in Cheung, 2009). According to Cheung (2009), the validity of many attitude instruments is so notorious that science researchers do not trust the quantitative data generated by these instruments and that instrument developers have been criticized for failure to properly address validity. Many developers use only a panel of judges to evaluate their instruments for validity. According to Wang \& Berlin (2010), the science attitude instruments developed to date have been critiqued closely, and a number of problems and weaknesses in them have been reported. Central to these critiques is the lack of clarity and definition of the underlying attitude construct being measured. Osborne et al. (2003) cited in Wang \& Berlin (2010), noted that attitudes toward science may not consist of a single construct but consist of many different constructs. If there is no single construct underlying a scale, combining unrelated items into a single total is unjustified psychometrically.

\section{Literature Review}

An attitude may be defined as a predisposition to respond in a favorable or unfavorable manner with respect to a given attitude object (Oskamp \& Schultz, 2005; Cheung, 2011). The attitude object can be anything, such as chemistry, chemists, chemistry lessons, topics taught in school chemistry, inquiry-based chemistry laboratory experiments, chemical education research, chemical weapons, or industrial chemistry (Cheung, 2011).

Oskamp and Schultz (2005) described that there are three major theoretical viewpoints about the important nature of attitudes that have been proposed by social psychologists: the tri-component point of view, the separate entities point of view, and the latent process perspective. Affect, behaviour, and cognition are the three components of attitude which is a single entity the tri-component viewpoint holds. The thoughts and emotions one has toward an attitude object such as chemistry lessons and chemistry as a subject are referred to as affective point of view. The individual's explicit events and reactions to the attitude object is referred to as behavior component of attitude, while the cognitive factor is the thinking or belief that someone has about the attitude object. The second theoretical viewpoint about the nature of attitudes assumed that the three components, affect, behavior and cognition are unique and separate entities.

The third theoretical point of view views attitudes as a latent variable that can explain the connection between certain observable stimulus events and behaviors.

Attitudes have been demonstrated to influence and be influenced by achievement and by cognition respectively. Researches demonstrated that there is a link between the cognitive and the affective and that chemistry education goals should embrace the two and not treat them as mutually exclusive domains. According to Mbajiorgu et al (2006), there are four areas where attitudes are important: attitudes towards chemistry; attitudes towards topics and themes in chemistry; attitudes towards the learning of chemistry; and scientific attitudes. According to Xu (2010), given a particular object about which an attitude exists, "cognition" refers to how people think about the object, i.e. knowledge and beliefs about properties of the object (including both favorable and unfavorable judgments). "Affect" pertains to how people feel about the object (both good and bad feelings), as expressed via physiological activity or overt communication. "Behaviour" is overt actions with respect to the object as well as intentions to act (again, both positive and negative actions and intentions).

\section{Methodology}

\subsection{Sample}

The population of study is all second-year chemistry students of Damongo Senior High School. Simple random sampling was used to choose students. Finally, a total of 100 SHS form 2 students ( 80 boys and 20 girls) participated in the study.

\subsection{Instrumentation}

The Attitude towards Electrochemistry Scale (ATECS) was used to measure students' attitude towards electrochemistry. This was a modified version of the 12-item attitude towards chemistry lessons scale (ATCLS) developed by Cheung (2011). The attitude towards electrochemistry Scale (ATECS) consisted of 14 Likert-type questions on a fivepoint scale measuring students' attitude towards electrochemistry. Each item consisted of a statement followed by five options namely Strongly Agree (SA), Agree (A), Undecided (U), Disagree (D) and Strongly disagree (SD). Table 1 presents examples of some items of the ATECS.

\begin{tabular}{|c|c|c|c|c|c|c|}
\hline S/N & Items & \multicolumn{5}{|c|}{ Responses } \\
\hline 1 & $\begin{array}{c}\text { I like electrochemistry more than any other } \\
\text { chemistry topic. }\end{array}$ & SA & A & U & D & SD \\
\hline 2 & Electrochemistry lessons are interesting & SA & A & U & D & SD \\
\hline 3 & $\begin{array}{c}\text { Electrochemistry is one of my favorite chemistry } \\
\text { topics }\end{array}$ & SA & A & U & D & SD \\
\hline 4 & I like to do electrochemistry experiments & SA & A & U & D & SD \\
\hline
\end{tabular}

Table 1: Sample Items in the Attitude Scale (ATECS) 
The ATECS consists of four subscales namely;

- Liking for electrochemistry theory lessons,

- Evaluative beliefs about electrochemistry,

- Chemistry anxiety.

- Liking for chemistry experiments.

The first subscale consists of four items and focuses on the feelings a student has toward the chemistry theory lessons implemented in school. This subscale is concerned with affective attitudinal responses. Bem cited in Cheung (2009) simply defined attitudes as likes and dislikes. According to Eagly and Chaiken cited in Cheung (2009), this dimension must be included in any measures of attitude toward a school subject because psychologists have reached a consensus that people have attitudes when they love or hate things and when they approve or disapprove of them. For example, Parkinson et al. (1998) conducted an exploratory factor analysis and found that nine of their attitude items formed a factor labeled as enjoyment, which accounted for the greatest percentage of variance of the variables. Items used by Parkinson et al. included 'I think science is interesting' and 'Science is my favourite subject'.

The second subscale is cognitive in nature and refers to the evaluative beliefs that a student holds about the importance and usefulness of school chemistry. It consists of three items: 'I am willing to spend more time reading chemistry textbooks', 'when I am working in the chemistry laboratory I feel I am doing something important' and 'chemistry is one of my favorite subjects'.

Oskamp and Schultz (2005) explained that evaluative beliefs are beliefs that state a value judgment about an attitude object. According to Cheung (2009), examples of attitude items used by science educators to measure the importance or usefulness of chemistry lessons are;

- Chemistry is a very worthwhile and necessary subject.

- Chemistry knowledge is useful to interpret many aspects of our everyday life.

- Every high school graduate needs some knowledge of chemistry, and

- Chemistry is an essential prerequisite to the study of other natural sciences.

The third subscale consists of four items and it is about students feeling of fear or anxiety towards chemistry as a subject, chemistry tests, chemistry teacher or chemistry classroom environment. The fourth subscale consists of three items and it is about students liking for electrochemistry experiments. Laboratory work is a key component of school science, and research has indicated that the majority of science students like doing laboratory work in science lessons. An attitude study by Parkinson et al. cited in Cheung (2009) revealed that 'The most common feature that attracted students to science was the amount of practical work involved'. Chemistry practical work received the largest number of favorable comments. The internal consistency reliability of the adapted ATECS was adequate with the Cronbach alpha values of the four subscales ranging from .683 to .855 (Table 2).

\begin{tabular}{|c|c|c|}
\hline Sub-Scale & $\begin{array}{c}\text { Items Comprising } \\
\text { Scale }\end{array}$ & $\begin{array}{c}\text { Cronbach } \\
\text { Alpha }\end{array}$ \\
\hline Liking for Electrochemistry & $1,2,3,4$ & 0.765 \\
\hline Evaluative Beliefs about Electrochemistry & $5,6,7$ & 0.683 \\
\hline Chemistry Anxiety & $8,9,10,11$ & 0.855 \\
\hline Liking for Chemistry Experiments & $12,13,14$ & 0.751 \\
\hline
\end{tabular}

Table 2: Factors/Variables, Items and Alpha Values Making the ATECS

\section{Results}

\subsection{Pilot test of the ATECS}

A pilot test of the initial version of the Attitude towards Electrochemistry Scale (ATECS) was carried out with a sample of 100 SHS2 chemistry students in Damongo Senior High School to establish the validity and reliability of the instrument. The initial version of the scale consisted of 20 items with seven sub-scales. The students in the experimental and control groups were not part of this sample. The pilot test was also necessary to correct errors and identify ambiguous and difficult items.

\subsection{Reliability of the ATECS}

To measure the reliability of the scale and internal consistency, Cronbach alpha coefficient was used. The Cronbach alpha $(\alpha)$ value of the 20 items was .866. Analysis of the corrected item-total correlations of the 20 items revealed six items with low item-total correlations below .3. After deleting the six items (items 1, 6, 7, 15, 17, and 20), the reliability procedure was rerun and the Cronbach alpha increased from .866 to .906 . This value is quite high and indicated that the items form a scale that has reasonable internal consistency reliability. Also, the corrected item-total correlations of the 14 items were high ranging between .530 and .760. The minimum level of alpha coefficient of a good test is 0.7 , which has been suggested by Nunnally (1978). Therefore, the ATECS form a reliable scale. 


\begin{tabular}{|c|c|c|}
\hline Cronbach's Alpha & $\begin{array}{c}\text { Cronbach's Alpha Based } \\
\text { on Standardized Items }\end{array}$ & N of Items \\
\hline .906 & .918 & 14 \\
\hline
\end{tabular}

Table 3: Reliability Statistics of the ATECS

\begin{tabular}{|c|c|c|}
\hline Item & $\begin{array}{c}\text { Corrected Item- } \\
\text { Total Correlation }\end{array}$ & $\begin{array}{l}\text { Cronbach's Alpha if } \\
\text { Item Deleted }\end{array}$ \\
\hline $\begin{array}{l}\text { 1. I like trying to solve new problems in } \\
\text { chemistry }\end{array}$ & .587 & .900 \\
\hline 2. Chemistry lessons are interesting & .603 & .900 \\
\hline $\begin{array}{l}\text { 3. Chemistry is one of the most important } \\
\text { subjects for people to study. }\end{array}$ & .615 & .899 \\
\hline 4. I consider myself a good chemistry student & .730 & .898 \\
\hline $\begin{array}{l}\text { 5. I am willing to spend more time reading } \\
\text { chemistry books }\end{array}$ & .585 & .900 \\
\hline $\begin{array}{l}\text { 6. When I am working in the chemistry lab, I } \\
\text { feel I am doing something important. }\end{array}$ & .710 & .896 \\
\hline 7. Chemistry is one of my favorite subjects & .552 & .902 \\
\hline 8. Chemistry tests make me afraid & .530 & .903 \\
\hline $\begin{array}{l}\text { 9. In chemistry class I feel being in control of my } \\
\text { learning }\end{array}$ & .688 & .899 \\
\hline $\begin{array}{l}\text { 10. My chemistry teacher makes me feel as if I } \\
\text { am a dumb }\end{array}$ & .605 & .900 \\
\hline $\begin{array}{l}\text { 11. Chemistry makes me feel as though I am lost } \\
\text { in the bush }\end{array}$ & .760 & .892 \\
\hline $\begin{array}{l}\text { 12. If I had a chance, I would do a project in } \\
\text { chemistry }\end{array}$ & .536 & .902 \\
\hline 13. I like to do chemistry experiments & .653 & .897 \\
\hline $\begin{array}{l}\text { 14. People must understand chemistry because it } \\
\text { affects their lives. }\end{array}$ & .660 & .897 \\
\hline
\end{tabular}

Table 4: Item-Total Statistics of 14 Items

\subsection{Descriptive Statistics}

Table 4 below shows the descriptive statistics of the ATECS. All the items have mean values above 3 . This intimates that students have more positive attitude towards the subject matter of the item. Higher standard deviations represent a wider dispersion of attitude in the subject matter of the item.

\begin{tabular}{|c|c|c|c|}
\hline Item & Mean & Std. Deviation & $\mathbf{N}$ \\
\hline 1. I like trying to solve new problems in chemistry & 4.16 & 1.10 & 100 \\
\hline 2. Chemistry lessons are interesting & 4.28 & .890 & 100 \\
\hline $\begin{array}{l}\text { 3. Chemistry is one of the most important subjects for } \\
\text { people to study. }\end{array}$ & 4.28 & 1.307 & 100 \\
\hline 4. I consider myself a good chemistry student & 4.80 & .645 & 100 \\
\hline 5. I am willing to spend more time reading chemistry books & 3.84 & 1.31 & 100 \\
\hline $\begin{array}{l}\text { 6. When I am working in the chemistry lab, I feel I am doing } \\
\text { something important. }\end{array}$ & 4.52 & .918 & 100 \\
\hline 7. Chemistry is one of my favorite subjects & 3.72 & 1.36 & 100 \\
\hline 8. Chemistry tests make me afraid & 4.36 & .700 & 25 \\
\hline 9. In chemistry class I feel being in control of my learning & 4.60 & .707 & 100 \\
\hline 10. My chemistry teacher makes me feel as if I am a dumb & 3.92 & 1.41 & 100 \\
\hline 11. Chemistry makes me feel as though I am lost in the bush & 3.92 & 1.46 & 100 \\
\hline 12. If I had a chance, I would do a project in chemistry & 4.72 & .737 & 100 \\
\hline 13. I like to do chemistry experiments & 4.12 & 1.20 & 100 \\
\hline $\begin{array}{l}\text { 14. People must understand chemistry because it affects their } \\
\text { lives. }\end{array}$ & 4.44 & 1.35 & 100 \\
\hline
\end{tabular}

Table 5: Means and Standard Deviations of Items in the ATECS 


\subsection{Factor Analysis}

To determine construct validity and identifying factors in items of scale, the exploratory factor analysis was used. A principal component factor analysis was performed on the remaining 14 items in ATECS with varimax rotation. Before the factor analysis, the Bartlett's Test of Sphericity and the value of KMO (Kaiser-Mayer-Olkin of sampling adequacy) were determined to make sure the data was suitable for factor analysis. The Bartlett's Test of Sphericity was significant $\chi^{2}=$ (261.232), $\mathrm{p}<0.05$, indicating that correlations between items were sufficiently large for factor analysis. Also, the KMO value was .606, above the proposed minimum values of 0.5 (Yong \& Pearce, 2013) and 0.6 as proposed by Tabachnick and Fidell (2007). This means that the data sample was adequate for factor analysis.

\begin{tabular}{|l|c|c|}
\hline \multicolumn{2}{|c|}{ Kaiser-Meyer-Olkin Measure of Sampling Adequacy. } & .606 \\
\hline Bartlett's Test of Sphericity & Approx. Chi-Square & 261.232 \\
\cline { 2 - 3 } & $\mathrm{df}$ & 91 \\
\cline { 2 - 3 } & Sig. & .000 \\
\hline
\end{tabular}

Table 6: KMO and Bartlett's Test

The internal consistency of each factor proved to be high, as indicated by Cronbach's alpha values that ranged between .683 and .855. Four factors were extracted instead of the original seven factors which was based on a priori theoretical beliefs about the number of underlying constructs. The factors are: Liking for Electrochemistry, Evaluative Beliefs about Electrochemistry, Chemistry Anxiety and Liking for Chemistry Experiments. The four factors accounted for $48.726 \%, 12.692 \%, 9.899 \%$ and $7.191 \%$ respectively of the variance of the 14 variables (in combination explained $78.508 \%$ of the variance). Table 6 shows the items and factor loadings for the rotated factors, with loadings less than .30 omitted.

\begin{tabular}{|c|c|c|c|c|c|c|c|c|c|}
\hline \multirow[t]{2}{*}{ Component } & \multicolumn{3}{|c|}{ Initial Eigenvalues } & \multicolumn{3}{|c|}{$\begin{array}{c}\text { Extraction Sums of Squared } \\
\text { Loadings }\end{array}$} & \multicolumn{3}{|c|}{$\begin{array}{c}\text { Rotation Sums of Squared } \\
\text { Loadings }\end{array}$} \\
\hline & Total & $\begin{array}{c}\% \text { of } \\
\text { Varianc } \\
\mathrm{e}\end{array}$ & $\begin{array}{c}\text { Cumulat } \\
\text { ive } \%\end{array}$ & Total & $\begin{array}{c}\text { \% of } \\
\text { Varianc } \\
\mathrm{e}\end{array}$ & $\begin{array}{c}\text { Cumulat } \\
\text { ive } \%\end{array}$ & Total & $\begin{array}{c}\% \text { of } \\
\text { Varianc } \\
\mathrm{e}\end{array}$ & $\begin{array}{c}\text { Cumulat } \\
\text { ive } \%\end{array}$ \\
\hline 1 & 6.822 & 48.726 & 48.726 & 6.822 & 48.726 & 48.726 & 3.118 & 22.271 & 22.271 \\
\hline 2 & 1.777 & 12.692 & 61.418 & 1.777 & 12.692 & 61.418 & 2.980 & 21.285 & 43.556 \\
\hline 3 & 1.386 & 9.899 & 71.317 & 1.386 & 9.899 & 71.317 & 2.782 & 19.874 & 63.430 \\
\hline 4 & 1.007 & 7.191 & 78.508 & 1.007 & 7.191 & 78.508 & 2.111 & 15.079 & 78.508 \\
\hline 5 & .795 & 5.679 & 84.188 & & & & & & \\
\hline 6 & .688 & 4.913 & 89.101 & & & & & & \\
\hline 7 & .440 & 3.140 & 92.241 & & & & & & \\
\hline 8 & .355 & 2.537 & 94.777 & & & & & & \\
\hline 9 & .256 & 1.826 & 96.603 & & & & & & \\
\hline 10 & .215 & 1.539 & 98.142 & & & & & & \\
\hline 11 & .118 & .846 & 98.988 & & & & & & \\
\hline 12 & .065 & .466 & 99.453 & & & & & & \\
\hline 13 & .055 & .389 & 99.843 & & & & & & \\
\hline 14 & .022 & .157 & 100.000 & & & & & & \\
\hline
\end{tabular}

Table 7: Total Variance Explained

Extraction Method: Principal Component Analysis

The screen test (Fig.1) is a plot of eigenvalues and factors (Cattell, 1978). An inspection of the scree plot revealed a clear break at the point of inflexion after the fourth factor. The number of factors retained is the data points that are above the break or point of inflexion (Yong \& Pearce, 2013). This confirms the four factors by the Kaiser's criterion and thus four factors were retained. 


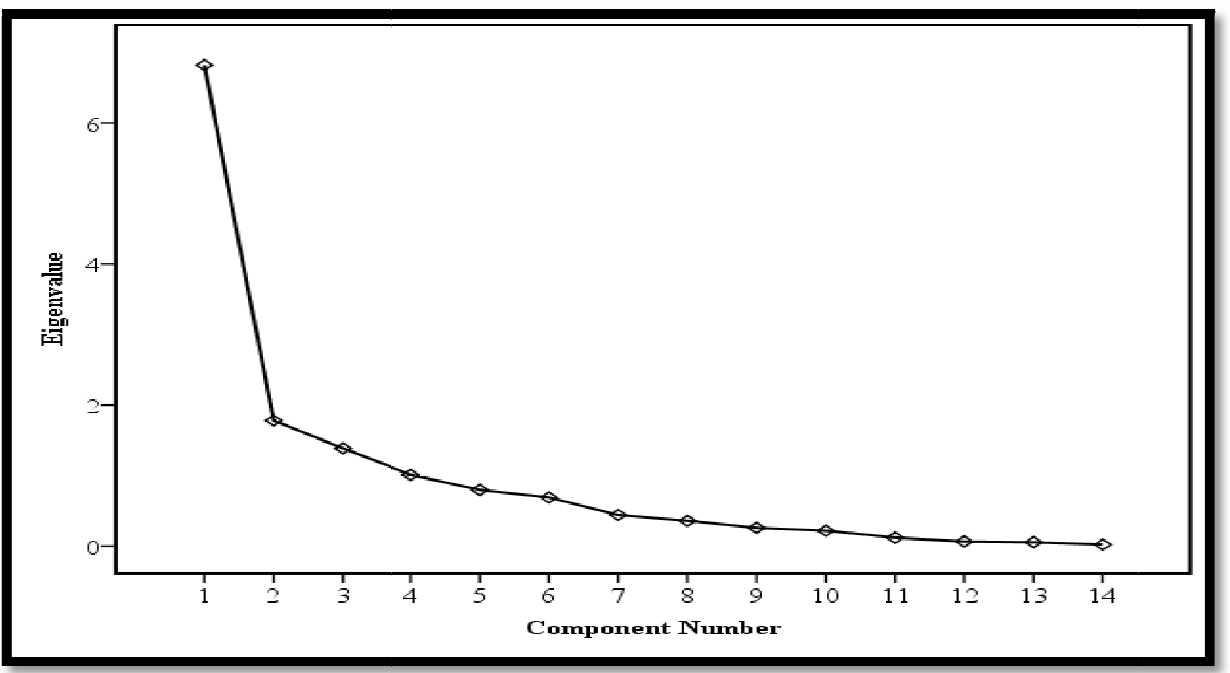

Figure 1: Scree Plot

After factor analysis, the items which loaded less than .30 on the relevant factors were ignored. The factor loadings were reasonable with values between .40 and .883 (Table 6). According to Tabachnick and Fidell (2007), only variables with loadings of .32 and above are interpreted. The greater the loading, the more the variable is a pure measure of the factor. Comrey and Lee cited in Tabachnich and Fidell (2007) suggested that loadings that exceed .71 (50\% overlapping variance) are considered excellent, .63 (40\% overlapping variance) very good, .55 (30\% overlapping variance) good, .45 (20\% overlapping variance) fair, and .32 (10\% overlapping variance) poor. Based on this, the factor loadings of the variables appeared to be good. Some of the items were loaded unto more than one factor (cross loading), and so the magnitude of factor loadings as well as the relevance of the items to the underlying constructs were taken into consideration in the analysis. Items with high factor loadings and are more relevant to the underlying construct were retained.

Factors were interpreted or named by examining the largest values linking the factor to the measured variables in the rotated factor matrix (Green \& Salkind, 2005). Some of the items were retained under other factors and some factors were renamed. The factors are: Liking for Electrochemistry, Evaluative Beliefs about Electrochemistry, Chemistry Anxiety and Liking for Chemistry Experiments. The total number of items was 14. Factor 1 and factor 3 had 4 items each whiles factor 2 and factor 4 has 3 items each.

\begin{tabular}{|c|c|c|c|c|c|}
\hline \multicolumn{6}{|c|}{ Rotated Factor loadings $(\mathrm{N}=\mathbf{1 0})$} \\
\hline & $\begin{array}{c}\text { Item-total } \\
\text { correlations }\end{array}$ & $\begin{array}{c}\text { Factor } \\
1 \\
\end{array}$ & $\begin{array}{c}\text { Factor } \\
2 \\
\end{array}$ & $\begin{array}{c}\text { Factor } \\
3 \\
\end{array}$ & $\begin{array}{c}\text { Factor } \\
4 \\
\end{array}$ \\
\hline Item 1 & 0.536 & 0.883 & & & \\
\hline Item 2 & 0.530 & 0.786 & & & \\
\hline Item 3 & 0.710 & 0.500 & & & \\
\hline Item 4 & 0.587 & 0.400 & & & \\
\hline Item 5 & 0.552 & & 0.759 & & \\
\hline Item 6 & 0.603 & & 0.674 & & \\
\hline Item 7 & 0.730 & & 0.497 & & \\
\hline Item 8 & 0.653 & & & 0.881 & \\
\hline Item 9 & 0.760 & & & 0.827 & \\
\hline Item 10 & 0.660 & & & 0.702 & \\
\hline Item 11 & 0.605 & & & 0.461 & \\
\hline 1tem 12 & 0.615 & & & & 0.802 \\
\hline Item 13 & 0.585 & & & & 0.655 \\
\hline Item 14 & 0.688 & & & & 0.560 \\
\hline $\begin{array}{c}\% \text { of variance } \\
\text { explained }\end{array}$ & & $48.72 \%$ & $12.69 \%$ & $9.89 \%$ & $7.19 \%$ \\
\hline & lue & 6.82 & 1.77 & 1.38 & 1.00 \\
\hline
\end{tabular}

Table 8: Item-Total Correlations, Eigenvalues and Factor Loadings of Items of the ATECS

The factors were defined by eigenvalues greater than 1 according to the Kaiser-criterion (Tabachnick \& Fidell, 2007). The subscales of the ATECS and their corresponding items and alpha values are presented in Table 9. 


\begin{tabular}{|c|c|c|c|}
\hline Subscale and Item & Cronbach's $(\alpha)$ & $\begin{array}{c}\text { Factor } \\
\text { Loadings }\end{array}$ & $\begin{array}{c}\text { Item-total } \\
\text { correlation }\end{array}$ \\
\hline Liking for Electrochemistry & 0.76 & & \\
\hline I like trying to solve new problems in electrochemistry. & & 0.88 & 0.53 \\
\hline Electrochemistry lessons are interesting. & & 0.78 & 0.58 \\
\hline Electrochemistry is one of the most important subjects for people to study. & & 0.50 & 0.71 \\
\hline I consider myself a good chemistry student. & & 0.40 & 0.53 \\
\hline Evaluative/Behavioral Beliefs & 0.68 & & \\
\hline I am willing to spend more time reading chemistry books. & & 0.75 & 0.55 \\
\hline $\begin{array}{c}\text { When I am working in the chemistry lab, I feel I am } \\
\text { doing something important }\end{array}$ & & 0.67 & 0.60 \\
\hline Chemistry is one of my favorite subjects. & & 0.49 & 0.73 \\
\hline Chemistry Anxiety & 0.85 & & \\
\hline Chemistry tests make me afraid. & & 0.88 & 0.76 \\
\hline In electrochemistry class I feel being in control of my learning. & & 0.82 & 0.65 \\
\hline My chemistry teacher makes me feel as if I am a dumb. & & 0.70 & 0.66 \\
\hline Chemistry makes me feel as though I am lost in the bush. & & 0.46 & 0.605 \\
\hline Liking for Chemistry Experiments & 0.75 & & \\
\hline If I had a chance, I would do a project in electrochemistry. & & 0.80 & 0.68 \\
\hline I like to do chemistry experiments. & & 0.65 & 0.61 \\
\hline People must understand electrochemistry because it affects their lives. & & 0.56 & 0.58 \\
\hline
\end{tabular}

Table 9: Cronbach Alpha, Corrected Item-Total Correlations, and Loadings of Items of ATECS

\section{Discussion}

The aim of the study was to develop and validate a theoretically based instrument designed to measure the attitude of students towards electrochemistry. Different analysis methods were used to establish the validity and the internal consistency of the instrument and the subscales it entails. The excellent results of the validation procedure show that the ATECS is capable of measuring the multiple dimensions of students' attitudes toward electrochemistry. Criterion validity was determined by conducting factor analysis on the data of a group of 100 students. The resulting factor structure corresponded to the underlying theoretical model, consisting of four factors or dimensions of attitude towards electrochemistry namely liking for electrochemistry $(\alpha=.76)$, evaluative/behavioral beliefs about electrochemistry $(\alpha=$ $.68)$, chemistry anxiety $(\alpha=.85)$ and liking for chemistry experiments $(\alpha=.75)$.

Cheung (2011) developed a scale to measure students' attitude towards chemistry lessons (ATCLS). The ATCLS consisted of 12 items with four factors which are; liking for chemistry theory lessons $(\alpha=.86)$, liking for chemistry laboratory work ( $\alpha=.84)$, evaluative beliefs about school chemistry $(\alpha=.76)$ and behavioral tendencies to learn chemistry $(\alpha=.76)$.The ATECS is a useful tool for the field of chemistry education and largely science education since it provides the opportunity to describe the attitude of students in a more detailed manner. The results of this study showed that the entire ATECS has good validity and reliability (coefficient alpha .906). The findings are consistent with of Simpson and Oliver (1990), Atawater et al. (1995), Greenfield (1997) and Spellman and Oliver (2001) which respectively have calculated this coefficient alpha to be $.88, .88, .92$ and .87 .

Also, Scantlebury et al. (2007) cited in Wang \& Berlin (2010), developed an instrument to measure students' performance and attitudes toward science from elementary school to college. The Cronbach's alpha coefficient for the scale of attitudes toward science was 0.94 . The validity was verified by only one expert panel in science education. Sorge (2007) cited in Wang \& Berlin (2010), designed a 10-item attitude toward science scale to investigate the association of age and gender with science attitudes from elementary to middle school. The Cronbach alpha for the instrument was 0.96, but no validity data were reported.

The Results showed that the first factor, liking for electrochemistry has highest explaining the variance (48.72\%). This intimates that the factor that makes students' attitudes students more positive toward electrochemistry and attracts them to chemistry is liking or interest in electrochemistry. Liaghatdar, Soltani and Abedi (2011) found that science is fun accounted for $16.76 \%$ of the variance explained in a validity study of attitude toward science. The factors evaluative/behavioral beliefs and chemistry anxiety with $12.69 \%$ and $9.89 \%$ of variance respectively also play a significant role in the attitude of students toward electrochemistry. This issue shows that the beliefs of students about the usefulness of electrochemistry and their fear for electrochemistry affect their attitude towards electrochemistry. 
Again Liaghatdar, Soltani and Abedi (2011) reported in their study that anxiety towards science accounted for $3.59 \%$ of the variance explained. The factor liking for chemistry experiments explained $7.19 \%$ of the variance. This explains that chemistry experiments are very important in fostering students' interest to learn chemistry and thus affects their attitude toward chemistry. Therefore, teachers and curriculum planners should include more practical lessons in teaching and design of chemistry curriculum. Wang and Berlin (2010) in their study on Construction and Validation of an Instrument to Measure Taiwanese Elementary Students 'Attitudes toward Their Science Class extracted only one factor using Catell's (1966) scree test and Horn's (1965) parallel analysis which accounted for $32.91 \%$ of the variance. Some of the items in their scale include: in a science class, doing experiments is boring, in science class experiments are difficult, the experiments I do in science class are useful, I enjoy reading the science textbook, science class is interesting and I am afraid to answer questions in science class.

\section{Conclusion}

The ATECS proves to be a promising scale within the field of science education at the senior high school level. It can be utilized as a research instrument for effective studies of students' attitude towards chemistry. And finally, it can be used as a guiding tool for making senior high school students aware of their own view of chemistry and their attitude toward chemistry learning.

\section{References}

i. Abulude, O. F. (2009). Students' Attitude towards Chemistry in Some Selected Secondary Schools in Akure South Local Government Area, Ondo State. Unpublished Thesis of PGD in Education. Retrieved October 2, 2015.

ii. Akram, M., Bin Surif, J. \& Ali, M. (2014). Conceptual Difficulties of Secondary School Students in Electrochemistry. Journal of Asian Social Science. 10 (19), Retrieved from: http://dx.doi.org/10.5539/ass.v10n19p276 on $7^{\text {th }}$ September, 2015. DOI:10.5539/ass. v10n19p276

iii. Atawater, M. M., Wiggins, J., \& Gardner, C. M. (1995). A study of urban middle school students with high and low attitudes toward science. Journal of Research in Science Teaching, 32, 665-667. http://dx.doi.org/10.1002/tea.3660320610

iv. Bennett, J., Rollnick, M., Green, G. and White, M. (2001). The Development and Use of an Instrument to Assess Students' Attitude to the Study of Chemistry. International Journal of Science Education, 23(8), 833-845.

v. Cattell, R. B. (1978). The Scientific Use of Factor Analysis in Behavioral and Life Sciences. New York, NY: Plenum Press.

vi. Cheung, D. (2009) Developing a Scale to Measure Students' Attitudes toward Chemistry Lessons, International Journal of Science Education, 31:16, 2185-2203, DOI: 10.1080/09500690802189799. http://dx.doi.org/10.1080/09500690802189799

vii. Cheung, D. (2011). Evaluating Student Attitudes toward Chemistry Lessons to Enhance Teaching in the Secondary School. Educ. quím., 22(2), 117-122, 2011.

viii. Dalgety, J., Coll, R. K., \& Jones, A. (2003). Development of Chemistry Attitudes and Experiences Questionnaire (CAEQ). Journal of Research in Science Teaching, 40(5), 649-668.

ix. Glasman, L. R. \& Albarracin, D. (2006). Forming Attitudes That Predict Future Behavior: A Meta-Analysis of the Attitude-Behavior Relation. Psychological Bulletin. 132(5), 778-822, 2006.

x. Green, S. B. \& Salkind, N. J. (2005). Using SPSS for Windows and Macintosh: Analyzing and Understanding Data (4th Edition). Prentice-Hall. Upper Saddle River, New Jersey.

xi. Greenfield, T. A. (1997). Gender- and grade-level differences in science interest and participation, Science Education, 81, 259-276. http://dx.doi.org/10.1002/(SICI)1098-237X(199706)81:3<259::AID-SCE1>3.0.C0;2-C

xii. Horn, J. L. (1965). An empirical comparison of various methods for estimating common factor scores. Educational and Psychological Measurements, 25, 313-322.

xiii. Kelly, A. (1988). The Customer Is Always Right: Girls' and Boys' Reactions to Science Lessons. School Science Review, 69(249), 662-676.

xiv. Liaghatdar, M.J., Soltani,A., Abedi, A. (2011). A Validity Study of Attitudes toward Science Scale among Iranian Secondary School Students. International Education Studies Vol. 4, No. 4; November 2011. www.ccsenet.org/ies

xv. Mbajiorgu, N. \& Reid, N. (2006). Factors Influencing Curriculum Development in Chemistry. Journal of the Royal Society of Chemistry. Tertiary Education Group. Higher Education Academy Physical Sciences Centre, (16)9

xvi. Nunnally, J. C. (1978). Psychometric theory (2 ${ }^{\text {nd }}$ Ed.).New York: McGraw-Hill.

xvii. Oliver J. S., \& Simpson R. D. (1990). A summary of major influences on attitude toward and achievement in science among adolescent students. Science Education, 74(1), 1-18.

xviii. Oskamp, S. \& Schultz, P. W. (2005). Attitudes and Opinions. (3 ${ }^{\text {rd }}$ Ed.), Mahwah, New Jersey. Lawrence Erlbaum.

xix. Owen, S. V., Toepperwein, M., Lichtenstein, M. J., Blalock, C. L., Liu, Y., Pruski, L. A., \& Grimes, K. (2008). Finding pearls: Psychometric reevaluation of the Simpson-Troost attitude questionnaire, Science Education, 92(6), 10761095. http://dx.doi.org/10.1002/sce.20296

xx. Parkinson, J., Hendley, D., Tanner, H., \& Stables, A. (1998). Pupils' attitudes to science in key stage 3 of the national curriculum: A study of pupils in South Wales. Research in Science and Technological Education, 16(2), 165-176.

xxi. Salta, K., \& Tzougraki, C. (2004). Attitudes toward Chemistry among 11th Grade Students in High Schools in Greece. Science Education, 88(4), 535-547. http://dx.doi.org/10.1002/sce.10134. 
xxii. Sia, D. T., Treagust, D. F. \& Chandrasegaran, A. L. (2012).High School Students' Proficiency and Confidence Levels in Displaying Their Understanding of Basic Electrolysis Concepts. International Journal of Science and Mathematics Education, 10 (6), pp. 1325-1345. http://doi.org/10.1007\%2Fs10763-012-9338-z

xxiii. Sirhan, G. (2007).Learning Difficulties in Chemistry: An Overview. Journal of Turkish Science Education, 4 (2),September. Retrieved from http://www.tused.org on $2^{\text {nd }}$ November, 2015.

xxiv. Tabachnick, B. G., \& Fidell, L. S. (2007). Using Multivariate Statistics (5 ${ }^{\text {th }}$ Ed.). Boston, Pearson Education.

xxv. Taber, K. S., (2002). Alternative Conceptions in Chemistry: Prevention, Diagnosis and Cure? London.The Royal Society of Chemistry.

xxvi. Tapia, M., \& Marsh, G. E. (2004). An instrument to measure mathematics attitudes. Academic Exchange Quarterly, $8(2), 16-21$.

xxvii. Wang, T-L. \& Berlin, D. (2010) Construction and Validation of an Instrument to Measure Taiwanese Elementary Students 'Attitudes toward Their Science Class, International Journal of Science Education, 32:18, 2413-2428, DOI:10.1080/09500690903431561. http://dx.doi.org/10.1080/09500690903431561

xxviii. Weinburgh, M. (1995). Gender Differences in Student Attitudes toward Science: A meta-analysis of the literature from 1970 to 1991. Journal of Research in Science Teaching, 32(4), 387-398.

xxix. Xu, X. (2010). Refnement of a Chemistry Attitude Measure for College Students. Graduate Theses and Dissertations. htp://scholarcommons.usf.edu/etd/1816

xxx. Yong, A. G., \& Pearce, S. (2013).A Beginner's Guide to Factor Analysis: Focusing on Exploratory Factor Analysis.Tutorials in Quantitative Methods for Psychology, 9(2), pp. 79-94. 